\title{
Performance and selection of tomato cultivars for organic cultivation in greenhouse ${ }^{1}$
}

\author{
Alex José Santa Rosa ${ }^{2 *}$ D, Fernando César Sala e Jean Carlos Cardoso ${ }^{2}$
}

10.1590/0034-737X201966020003

\begin{abstract}
Production of tomato fruits in organic systems has difficulties such as the use of adequate cultivars. The hypothesis is that organic cultivation has strength dependency of the selection of appropriate genotypes to increase the economic viability of fruit production. The present work aimed to test and obtain, under organic greenhouse system, cultivars of tomato with good fruit productivity. Tomato cultivars, hybrids and non-hybrids, were evaluated with undetermined (tutoring and stripping) and determined growth habit (free growth). In the first cultivation, we observed symptoms of nutritional deficiency in fruiting stage of tomato plants, resulting in very low productivity of fruits, with maximum of 1.8 $\mathrm{kg} / \mathrm{plant}$ for the Serato hybrid. In the second year of cultivation, the additions and increases in fertilizing management increased the fruit productivity in all cultivars - in Serato, to $3.1 \mathrm{~kg} / \mathrm{plant}$, and in Predador, to $2.8 \mathrm{~kg} / \mathrm{plant}$. The hybrid Candieiro, with determined habit growth, resulted in $2.0 \mathrm{~kg} / \mathrm{plant}$ of fruits. The use of hybrids with genetic resistance to some important pests and diseases, associated with increases and adequate fertilizing management, were primordial factors to increase fruit productivity in tomato under organic systems in greenhouse.
\end{abstract}

Keywords: Solanum lycopersicum L.; hybrids; determined $\times$ undetermined growth; fruit production; organic management.

\section{INTRODUCTION}

The estimated tomato production in 2018 was 4.1 million tons, being the vegetable of greater economic importance in Brazil, with concentration in production in the states of Goiás (32.5\%) and São Paulo (20.8\%) (SIDRA-IBGE, 2019). At the same time, the demand for organic tomatoes, as well as other organic foods, is increasing in Brazil and in the World nowadays.

The production of tomatoes in an organic farming system is still a challenge for the production of high-quality fruits with economically viable productivity and safely to the grower and the consumer. This is due to sustainable principles of the organic cultivation of tomatoes, based on the reduction in the use of natural resources, which reduces pollutant emissions and the generating products with a lower toxicity potential for the human and environment, compared with those produced in a conventional system
(He et al., 2016). The organic production of tomatoes presents main challenges, such as the choice of adapted cultivars (hybrid $\times$ open pollination), type of seeds, and nutritional and phytosanitary management (Luz et al., 2007, Mansour et al., 2014, Campos de Melo et al., 2009).

In addition, the question of use or non-use of tomato hybrid cultivars in organic agriculture is still unanswered. Some negative arguments for non-use is that this type of cultivar has higher demand of resources, such as water and fertilizers, to obtain high fruit productivities and the low genetic variability increasing its susceptibility to biotic and abiotic stresses, compared with non-hybrid cultivars. However, the current Brazilian and other international legislation about organic production do not prohibit the use of hybrids, which contains multiple resistance to important pests and phytopathogens and has higher shelf life (Melo et al., 2009; Maciel \& Silva, 2014).

\footnotetext{
Submitted on September 10 $0^{\text {th }}, 2018$ and accepted on February $14^{\text {th }}, 2019$.

${ }^{1}$ This work was obtained from the Conclusion Undergraduate Course of the first author.

${ }^{2}$ Universidade Federal de São Carlos, Departamento de Biotecnologia, Araras, São Paulo, Brazil. alexjsr2009@hotmail.com; jeancardoso@ufscar.br; fcsala@ufscar.br

*Corresponding: jeancardctv@gmail.com
} 
Due to the great number of pests and diseases in the tomato crop (Maciel \& Silva, 2014), organic cultivation requires better adapted technologies for phytosanitary management (Mansour et al., 2014). Compared with organic, conventional system has greater number of technologies available that help to obtain high yields of fruits and that are not applicable in organic cultivation. For example, the organic cultivation has several restrictions on the use of pesticides to control pests and diseases, as well as the use of high-solubility mineral sources, especially containing nitrogen, phosphorus, and potassium for fertilization management (Van Bruggen et al., 2016).

To solve some of these limitations in organic production, the use of greenhouses in tomato cultivation has shown benefits to increase productivity and precocity of fruit production, compared with field cultivation (O'Connel et al., 2012). However, the use of more suitable cultivars to organic production has aims at high productivity of fruits with quality to meet the market of organic tomatoes (Healy et al., 2017). Schwarz et al. (2013) emphasized that the performance tests of cultivars is important for the knowledge of the productive capacity and adaptability of the genotype to specific crop regions (genotype vs. environment). In addition, the use of cultivars with resistance to different types of pests and diseases is a way of correlating which factors are closely related to fruit yield, allowing future advances in breeding programs aiming at organic production systems.

Thus, the objective of this work was to evaluate the performance of tomato cultivars in an organic production system, cultivated under a protected environment (greenhouse conditions) in the spring-summer period, one of the most limiting times for tomato fruit production.

\section{MATERIALAND METHODS}

The experiments were conducted in the Santa Tereza Farm, in São Carlos, SP (854 m altitude). The climate of the region, according to Köeppen, is classified as tropical of altitude, Cwa, with rainy summer and dry winter. The two cultivations were carried out in spring/summer season (from October/2015 to March/2016 and the second from November/2016 to April/2017), period with the biggest problems for tomato fruit production in São Paulo (southeast Brazil), mainly due to the high temperatures and rainy season, which result in greater susceptibility of plants to biotic and abiotic factors.

The chemical characteristics of the soil was: $\mathrm{P}$ resine $=$ $71 \mathrm{mg} \mathrm{L}^{-1} ; \mathrm{MO}=11 \mathrm{mg} \mathrm{L}^{-1} ; \mathrm{pH}\left(\mathrm{CaCl}_{2)}=5.1 ; \mathrm{K}=1.2 \mathrm{mmolc}\right.$ $\mathrm{L}^{-1} ; \mathrm{Ca}=16$ mmolc L $^{-1} ; \mathrm{Mg}=5$ mmolc L $^{-1} ; \mathrm{H}+\mathrm{Al}=13$ mmolc $\mathrm{L}^{-1} ; \mathrm{Al}=0.2$ mmolc L ${ }^{-1} ; \mathrm{SB}=22.2$ mmolc L $^{-1} ; \mathrm{CTC}=35.2$ $\mathrm{mmolc} \mathrm{L}^{-1} ; \mathrm{V} \%=63 ; \mathrm{S}=15 \mathrm{mg} \mathrm{L}^{-1} ; \mathrm{B}=0.18 \mathrm{mg} \mathrm{L}^{-1} ; \mathrm{Cu}=15.8$ $\mathrm{mg} \mathrm{L}^{-1} ; \mathrm{Fe}=19 \mathrm{mg} \mathrm{L}^{-1} ; \mathrm{Mn}=4 \mathrm{mg} \mathrm{L}^{-1} ; \mathrm{Zn}=2.9 \mathrm{mg} \mathrm{L}^{-1}$.
The greenhouse had a central height of $2.5 \mathrm{~m}$ and lateral height of $1.3 \mathrm{~m}$, with anti-aphid screens on the sides and agricultural diffuser plastic of $150 \mu \mathrm{m}$ as top coverage. The irrigation system consisted of a drip type with flow of $6 \mathrm{~mm}$ day $^{-1}$ with irrigations done in the morning and afternoon, for $20 \mathrm{~min}$ in each period. After preparation of the soil, the beds were raised with the aid of a hoe, with 1 $\mathrm{m}$ wide and $0.2 \mathrm{~m}$ high, covered with bicolor silver (upside) and black (lowerside) mulch.

\section{First cultivation - 2015/2016}

During the soil preparation, $100 \mathrm{~g} \mathrm{~m}^{-2}$ of dolomitic agricultural limestone was applied 30 days before planting and $520 \mathrm{~kg}$ of $_{2} \mathrm{O}_{5}$ ha $^{-1}$ (Biofosfatos do Brazil, Araras, Brazil) and $1 \mathrm{~kg} \mathrm{~m}^{-2}$ of cattle manure one week before transplanting the seedlings. The cover fertilization was done with $36 \mathrm{~g} /$ plant of cattle manure $(1.5 \% \mathrm{~N} ; 1.2 \% \mathrm{P} ; 2.1 \% \mathrm{~K}$ - van Raij et al., 1996) every 15 days until the end of the experiment, following the recommendations of Fidélis Junior \& Cardoso (2016).

The seedlings were produced in plastic trays of 162 cells filled with Carolina Soil substrate (Pardinho, SP) for 40 days, being transplanted into the beds.

Seven cultivars of tomatoes were used as treatments: the hybrids 'Serato', 'Tyson', and 'Predador', with undetermined type of growth; the open-pollinated 'Santa Clara' and 'Santa Cruz', with undetermined type of growth; and the hybrids 'Candieiro' and 'Apolo', with determined type of growth. The types of fruits and the main characteristics of each cultivar are presented in Table 1.

The experiments were conducted in a completely randomized design, with five replications, consisting of plots containing five plants spaced $0.6 \mathrm{~m}$ between plants and $0.7 \mathrm{~m}$ between rows. In the determined cultivars, tutoring and elimination of axillary shoots were not performed.

For the undetermined-type cultivars, tutoring was performed using plastic tape for vertical cultivation up to $2.2 \mathrm{~m}$ (pinch) maintaining two rods. All axillary shoots were removed weekly using a scissor.

The evaluations started 24 days after transplanting and were performed every 14 days until the end of the experiment. The following morphological and horticultural characteristics were evaluated: plant height (cm), number of leaves per plant, and length and diameter of leaves $(\mathrm{cm})$. therein addition, we evaluated twenty fruits for each plot to obtain fruit individual weight, and productivity was calculated by measuring the total weight of fruits for each plant. We calculated the number of plants with symptoms of nutritional deficiency (in percentage), mainly associated with magnesium $(\mathrm{Mg})$ and nitrogen $(\mathrm{N})$ deficiencies, characterized by the plants with generalized chlorosis symptoms in old leaves 
(deficiency of $\mathrm{N}$ ) and by symptoms of yellowing between the leaf veins and around the leaf margins (deficiency of $\mathrm{Mg}$ ).

\section{Second cultivation 2016/2017}

Due to the low productivity and high percentage of plants with symptoms of nutritional deficiency observed in the first cultivation (2015/2016), the experiment was repeated in the year 2016/2017, with changes in fertilizing management. For this purpose, we performed a green fertilization with forage Brassica napus, incorporated in the soil with $40 \mathrm{~d}$ of cultivation, previously to tomato establishment. In addition, 2,700 $\mathrm{kg} \mathrm{ha}^{-1}$ of biophosphate were added. The seedlings were transplanted on 07/01/ 2017, following the methodology described in the first cultivation. Applications of $1 \mathrm{~kg} \mathrm{~m}^{-2}$ of chicken manure $(1.4 \% \mathrm{~N} ; 0.8 \% \mathrm{P} ; 0.7 \% \mathrm{~K}$ - van Raij et al., 1996) were carried out every 14 days as cover fertilizer, starting 14 days after transplanting the seedlings.

The cultivars used were the same of the first cultivation, except for the replacement of Santa Cruz by the undetermined-type hybrid Pioneiro, due to the very low productivity of Santa Cruz.

The experimental design was similar to the first one, but the cultivars with determined type of growth were drawn separately from the undetermined ones, avoiding the shading due to the type of conduction (shallow for determined and vertical for undetermined), avoiding undesirable shadowing of the undetermined to the determined types.

During the experiment, visual symptoms of nutritional deficiency were observed and corrected with foliar spray application of $0.5 \%$ magnesium sulphate and $0.15 \%$ boric acid solution. Four applications were performed at 14-day intervals, starting 60 days after transplanting.

The evaluations in the plants and fruits were similar to the first one, adding the evaluation of ${ }^{\circ}$ BRIX of the fruits. Two fruits per repetition were collected and used to deter- mine the total solid soluble contents. We used the refractometer HI96801 (Hanna Instruments, Portugal) for this analysis.

The data obtained in each cultivation year were separately subjected to Analysis of Variance (ANOVA), followed by a grouping mean test of Scott Knott means test at 5\% probability. The statistical software ASSISTAT version 7.7 (Santos e Silva \& Azevedo, 2016) was used for this purpose.

\section{RESULTS AND DISCUSSION}

It was possible to produce tomato fruits in organic system under protected cultivation in the summer conditions. The effect of cultivar was significant for the vegetative development and fruit production of tomato under organic system. It was observed that productivity was strongly influenced by the management of the plant nutrition, demonstrating that the use of appropriate genotypes associated with nutrition management were preponderant factors for the organic cultivation of tomato plants. The first crop served as a basis for understanding the main factors which limit the crop productivity, especially in relation to the nutritional requirements. The best management of nutritional requirements of tomato resulted in better fruit productivity in the second cultivation period compared with the first one.

The high percentage of plants with symptoms of nutritional deficiency was observed in first cultivation (Table 2). Although these symptoms could be confused with viruses, systemic diseases, and/or nematodes, in the second cultivation, there was a significant reduction in these symptoms, and the only difference between the crops was the management of the fertilization (Table 2).

The main differences observed in vegetative development of tomato plants were between undeterminedand determined-type cultivars (Table 3). The highest number of leaves observed in the determined type cultivars

Table 1: Characteristics and types of resistance of tomato cultivars used for the performance test under organic cultivation system in greenhouse. Source: Agristar do Brasil

\begin{tabular}{lcccccc}
\hline \multirow{2}{*}{ Cultivars } & Types & \multicolumn{4}{c}{ Types of resistence } \\
\cline { 3 - 7 } & of fruits & Nematode & TSWV & TYLCV & F3 & All \\
\hline Serato (H-I) & Khaki & $\mathrm{X}$ & $\mathrm{X}$ & & & Fol:0,1,For, On, ToMV, TSWV, Va e Vd \\
Predador (H-I) & Khaki & $\mathrm{X}$ & $\mathrm{X}$ & $\mathrm{X}$ & & Fol: 0, 1, For, Pf, TMV, ToMV, Va e Vd \\
Tyson (H-I) & Khaki & $\mathrm{X}$ & $\mathrm{X}$ & $\mathrm{X}$ & $\mathrm{X}$ & Fol: 0, 1, For, Pf, TMV, ToMV, Va e Vd \\
Apollo (H-D) & Khaki & & & $\mathrm{X}$ & & Fol: 0,1, Pf, ToMV, Va e Vd \\
Santa Clara (OP-I) & santa cruz & & & & Fol: 0, Ss, Va e Vd \\
Candieiro (H-D) & Italian & $\mathrm{X}$ & $\mathrm{X}$ & $\mathrm{X}$ & & Fol: 0,1, Ma, Mi, Mj, ToMV, Va e Vd \\
\hline
\end{tabular}

F1 hybrid with undetermined (H-I) or determined (H-D) growth habit and open-pollinated cultivars with undetermined growth habit (OPI). Description of types of resistance: TSWV; TYLCV - Tomato yellow leaf Curl virus; Fol - Fusarium oxysporum f.sp. lycopersici; For Fusarium oxysporum f.sp. radicis lycopersici; Ma - Meloidogyne arenaria; Mi - Meloidogyne incognita; Mj - Meloidogyne javanica; On - Oidium lycopersicum; ToMV - Tomato mosaic virus; TMV - Tobacco mosaic virus; Va - Verticillium albo-atrum; Vd - Verticillium dahliae; Pf - Passalora fulva; Ss - Stemphylium solani. 
was due to the different types of management carried out between these two types of cultivars. The undeterminedtype cultivars were vegetative managed with lateral shoot pruning and rises at $2.20 \mathrm{~m}$ height, while determined-type cultivars were maintained with free growth.

The hybrid cultivar Serato presented the highest individual fruit mass, with almost $200 \mathrm{~g}$ per fruit. Similar individual fruit masses were obtained in the cultivars Predador (170 g per fruit) and Apolo (160 g per fruit) (Figure 1). The lowest individual fruit masses were obtained in the openpollinated cultivar 'Santa Cruz' and the determined type hybrid Candieiro (Figure 1). These differences can be explained by the different fruit shapes and typologies among tested cultivars, resulting in differences in fruit mass. This can be observed by the differences in fruit diameter and fruit length (Table 2). For example, in the cultivar Candieiro with Italian-type fruit, the length of fruits $(8.2$ and $8.6 \mathrm{~cm})$ was superior to the other cultivars, with khaki type. The cultivars with the highest individual fruit mass (Serato, Predador, and Apolo), all with classic fruits, had the highest fruit diameters, with a mean of $6.5-6.7 \mathrm{~cm}$.
The sequence of cultivars from highest to lowest productivity observed was: Serato $(1.8 \mathrm{~kg} /$ plant $)>$ Predador $=$ Tyson $(1 \mathrm{~kg} /$ plant $)>$ Apollo $(0.8 \mathrm{~kg} /$ plant $)>$ Santa clara $(0.5 \mathrm{~kg} /$ plant $)>$ Candiero $(0.4 \mathrm{~kg} /$ plant $)>$ Santa Cruz (<0.4 kg/plant) (Figure 1).

A correlation between the number of plants with nutritional deficiency symptoms and fruit productivity was observed, i.e, the highest percentage of plants with symptoms of nutritional deficiency $(60 \%)$ was observed in the cv. 'Santa Cruz', associated with the lowest fruit productivity. The cv. Santa Cruz is a cultivar of the 1920s and has been widely cultivated; however, its susceptibility to the main pests and diseases limit its cultivation in conventional system. The same limitations were observed in this experiment using organic system, even in protected cultivation. Instead, the cv. Serato, which presented the highest fruit yield $(1.85 \mathrm{~kg} / \mathrm{plant})$ in the first cultivation, also presented the lowest percentage of plants with nutritional deficiency symptoms (Figure 1). The determined cultivars Candieiro and Apolo presented low fruit productivity ( 0.42 to 0.80

Table 2: Vegetative development and fruit characteristics of tomato cultivars under organic system cultivation in greenhouse. First (2015-2016) and second (2016-2017) cultivations

\begin{tabular}{|c|c|c|c|c|c|}
\hline \multirow{2}{*}{ Cultivars } & \multicolumn{2}{|c|}{ Number of leaves } & \multicolumn{2}{|c|}{ Lenght / diameter of fruit $(\mathrm{cm})$} & \multirow{2}{*}{$\begin{array}{c}{ }^{\circ} \text { Brix } \\
2016 / 2017\end{array}$} \\
\hline & 2015-2016 & 2016-2017 & $2015-2016$ & 2016-2017 & \\
\hline Predador & $34.4 \mathrm{~b}$ & $33.0 \mathrm{~b}$ & $5.6 \mathrm{~b} / 6.7 \mathrm{a}$ & $5.71 \mathrm{c} / 6.69 \mathrm{a}$ & $3.24 \mathrm{~b}$ \\
\hline Tyson & $32.8 \mathrm{~b}$ & $32.8 \mathrm{~b}$ & $5.5 \mathrm{~b} / 6.2 \mathrm{a}$ & $5.43 \mathrm{c} / 6.35 \mathrm{~b}$ & $4.33 \mathrm{a}$ \\
\hline Serato & $32.6 \mathrm{~b}$ & $33.8 \mathrm{~b}$ & $6.3 \mathrm{~b} / 6.7 \mathrm{a}$ & $5.77 \mathrm{c} / 6.66 \mathrm{a}$ & $3.84 \mathrm{a}$ \\
\hline Santa Clara & $34.5 \mathrm{~b}$ & $32.6 \mathrm{~b}$ & $5.2 \mathrm{~b} / 5.0 \mathrm{~b}$ & $5.55 \mathrm{c} / 4.85 \mathrm{c}$ & $4.19 \mathrm{a}$ \\
\hline Santa Cruz & $35.0 \mathrm{~b}$ & ne & $5.8 \mathrm{~b} / 4.6 \mathrm{~b}$ & ne & ne \\
\hline Pioneiro & ne & $34.7 \mathrm{~b}$ & ne & $7.29 \mathrm{~b} / 4.07 \mathrm{~d}$ & $4.45 \mathrm{a}$ \\
\hline Candieiro & $57.6 \mathrm{a}$ & $51.1 \mathrm{a}$ & $8.2 \mathrm{a} / 4.1 \mathrm{c}$ & $8.55 \mathrm{a} / 4.10 \mathrm{~d}$ & $3.53 \mathrm{~b}$ \\
\hline Apolo & $52.6 \mathrm{a}$ & $52.0 \mathrm{a}$ & $5.7 \mathrm{~b} / 6.5 \mathrm{a}$ & $5.67 \mathrm{c} / 6.73 \mathrm{a}$ & $3.92 \mathrm{a}$ \\
\hline $\bar{F}$ & $33.8^{*}$ & $113.2^{*}$ & $12.4^{*} / 52.8^{*}$ & $69.7 * / 413.1 *$ & 2.94 \\
\hline $\mathrm{CV} \%$ & 4.72 & 2.32 & $4.58 / 2.81$ & $2.24 / 1.15$ & 14.49 \\
\hline
\end{tabular}

*Means followed by the same lowercase letters in the columns constituted statistically homogeneous groups by the Scott-Knot means grouping test at $5 \%$ probability. ne $=$ not evaluated, $\mathrm{CV}=$ coefficient of variation.

Table 3: Fruit productivity, percentage of plants with nutritional deficiency symptoms, and percentage of increase in fruit productivity in cultivars of tomato under greenhouse organic cultivation

\begin{tabular}{|c|c|c|c|c|c|}
\hline \multirow{2}{*}{ Cultivars } & \multicolumn{2}{|c|}{$2015 / 2016$} & \multicolumn{2}{|c|}{$2016 / 2017$} & \multirow{2}{*}{$\begin{array}{c}\text { Increased } \\
\text { fruit yield }(\%)\end{array}$} \\
\hline & kg fruit/plant & Symptoms & kg fruit/plant & Symptoms & \\
\hline Predador & 1.03 & 25.7 & 2.8 & 8.5 & 171.8 \\
\hline Tyson & 0.99 & 34.3 & 1.78 & 5.7 & 79.8 \\
\hline Serato & 1.85 & 20 & 3.12 & 5.7 & 68.6 \\
\hline Santa Clara & 0.54 & 45.7 & 0.93 & 11.4 & 72.2 \\
\hline Santa Cruz & 0.38 & 60 & na & na & na \\
\hline Candieiro & 0.44 & 11.4 & 2.05 & 5.7 & 365.9 \\
\hline Apollo & 0.8 & 14.2 & 1.65 & 5.7 & 106.3 \\
\hline Pioneiro & na & na & 1.85 & 0 & na \\
\hline Mean & 0.86 & 30.2 & 2.03 & 6.10 & 144.1 \\
\hline
\end{tabular}


$\mathrm{kg} /$ plant) and were conducted without tutoring and randomized together with the undetermined cultivars, which caused shadowing exerted by the parcels of tutored plants.

The results obtained in the first crop defined some critical points for tomatoes cultivated under organic system, i.e, the use of cultivars resistant to the main viruses and that reduces the tomato fruit production is a necessary condition to obtain good fruit yields in this important crop, since the open-pollinated susceptible cultivars (Santa Cruz and Santa Clara) were those with lower productivity (Figure 1). The low fruit yields observed in all cultivars, associated with symptoms of nutritional deficiency, such as yellowing and falling leaves of the lower region of the plant, demonstrated the limitation in nutrient supply as a cause of low fruit yield.

For these reasons, the 2nd cultivation (summer 20162017) was based on fertilizing adjustments made regarding the results obtained in the first one. The planting and cover fertilizing significantly reduced the number of plants with symptoms of nutritional deficiency in the 2 nd cultivation (2016-2017; Table 2). The responses of tomatoes to the new fertilizing management showed increases in fruit yield per plant, independently of the cultivar used (Figure 1; Table 3).

Cultivar Predador showed greater individual fruit mass (> $180 \mathrm{~g} /$ fruit), similar to Serato (175 g/fruit). The cv. Apollo had a similar response to Serato with increase in individual fruit mass (170 g/fruit) compared with the first cultivation. The cultivar with the lowest fruit mass was Santa Clara (115 g/fruit), with similar results observed in the $1 \mathrm{st}$ cultivation (Table 3; Figure 1).

Although we observed small differences between the individual mass of the fruits between the 1st and 2nd cultivation, the highest gain, compared with the first crop 2015/2016, occurred for fruit productivity. The cv. Serato showed the highest fruit yield (> $3 \mathrm{~kg} / \mathrm{plant}$ ), at least 1.2 $\mathrm{kg} /$ plant more than in the first cultivation. The cv. Predador showed the second highest productivity, with $2.8 \mathrm{~kg} /$ plant, increasing $1.8 \mathrm{~kg} /$ plant compared with the previous cultivation. The cv. Pioneiro, tested for the first time in this experiment, yielded similar productivity to cvs. Tyson, Candieiro, and Apolo with 1.85, 1.78, 2.05, and $1.65 \mathrm{~kg} /$ plant, respectively (Table 3; Figure 1).
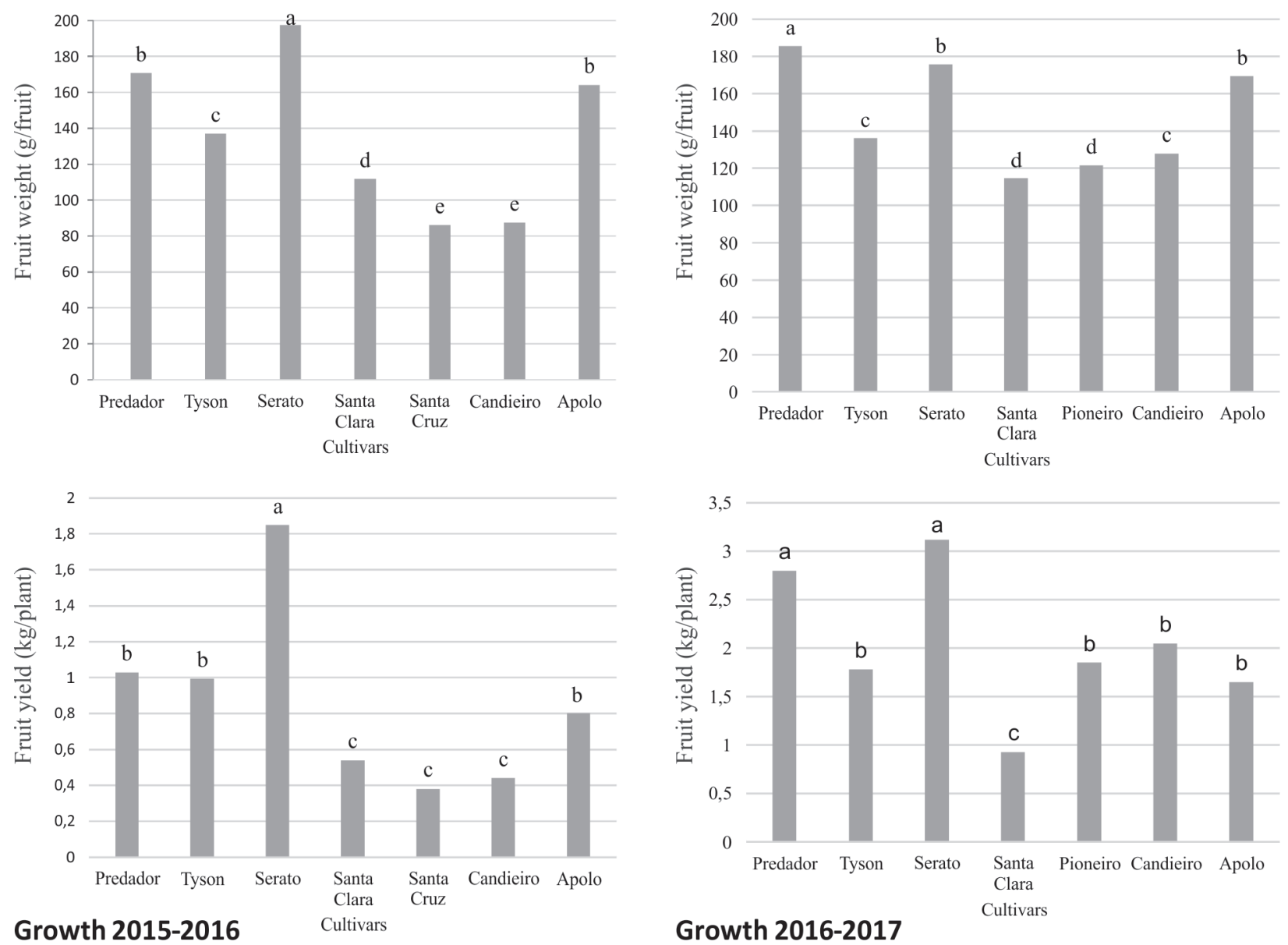

Growth 2016-2017

Figure 1: Individual weight and productivity of fruits of tomato cultivars cultivated under organic system in greenhouse, in the 1st (2015-2016) and 2nd (2016-2017) cultivation. Treatments with the same lower case letters above the columns constituted statistically homogeneous groups by the Scott-Knot mean test at 5\% probability

Rev. Ceres, Viçosa, v. 66, n.2, p. 094-101, mar/abr, 2019 
Regarding the cultivars with determined growth, Candieiro showed higher productivity than Apolo, differing from the results obtained in the 1st cultivation. However, in both cultivars, the fruit production increased, in relation to the first, with yields of 1.7 (Apolo) and $2.0 \mathrm{~kg} /$ plant (Candieiro) in the 2 nd cultivation.

The two consecutive experiments of tomato in organic systems showed a great effect of the genotype, aiming to select tomato cultivars more adapted to the organic production system. The undetermined hybrids Serato and Predador showed the highest fruit productivity using organic system in protected cultivation and under summer environmental conditions. The determined type cv. Candieiro also showed potential application for freegrowth cultivation.

Besides the genotype effect, the increase of cover fertilizing in the 2 nd cultivation resulted in an increase of $144.1 \%$, on average, in fruit yield. These great increases in productivity were the result of the increase of number of fruits produced per plant. An example is cv. Serato, in which dividing the fruit mass per plant by the individual mass of fruits, we have nine fruits/plant in the first cultivation (2015/ 2016), while in the second (2016/2017), this value was of 18.5 fruits/plant, more than double number of fruits. In the cv. Candieiro, this ratio was from 5.6 to 16.5 fruits/plant.

The increase in nutrient availability to the plants, through the supply of richer organic fertilizers in larger quantities, besides the supplements with magnesium sulphate and boric acid, resulted in better performance of all cultivars, contributing to the increase of fruit productivity (Table 3 ). This association can be confirmed by the reduction in the number of plants with symptoms of nutritional deficiency, which was reduced from $30.2 \%$ (1st) to $6.1 \%$ (2nd) using the new fertilizing management (Table 3).

Melo et al. (2009) observed that the hybrid cultivar Sahel showed commercial fruit yield of $3.9 \mathrm{~kg} / \mathrm{plant}$ and the other hybrid cultivars tested showed lower productivity (1.2 to $2.6 \mathrm{~kg}$ commercial fruits/plant). In the present work, the cultivar with the best fruit yield was Serato, with $3.1 \mathrm{~kg} /$ plant (Table 3; Figure 1). The experiment carried out by Melo et al. (2009) was conducted in the period from May to October (autumn/winter, in Brazil), the fertilizer used was compost-based $\left(200 \mathrm{~g} \mathrm{~m}^{-2}\right)$ and a single application of fertilizer via leaf at 46 days after transplanting with Supermagro fertilizer (0.3\%). Pedrosa et al. (2011) in Prudente de Morais, MG, Brazil, during the autumn/spring period under field conditions, obtained higher fruit yield using the San Vito cultivar, with $3.1 \mathrm{~kg} /$ plant. Vargas et al. (2004) also reported for organic cultivation, yields of 0.7 to $2.7 \mathrm{~kg} /$ plant in Rio de Janeiro under protected cultivation conditions in the fall/winter period, using Heirloom-type cultivars.
Using conventional system, the yield of tomatoes varies with the time of year, from 3 to $4 \mathrm{~kg} /$ plant in summer to $5 \mathrm{~kg} /$ plant in winter, whereas in the organic system, an average productivity is $4 \mathrm{~kg} / \mathrm{plant}$, with small variations according to the time of year (Luz et al., 2007). Although the fruit yield of the cultivar Serato, tested in this experiment, was close to the averages reported by Luz et al. (2007) in a conventional production system and by other authors under organic system, the data available in Agristar do Brasil reported fruit yields of $9 \mathrm{~kg} /$ plant for $\mathrm{cv}$. Serato (Agristar, 2016), under conventional greenhouse cultivation.

According to Melo et al. (2009), the use of F1 hybrid cultivars was beneficial to the organic system, being superior to non-hybrids. Likewise, in actual experiments, it was demonstrated that the use of F1 hybrids was superior to non-hybrids for fruit yield. These results were similar to those obtained by Toledo et al. (2011), who reported better commercial fruit yields with the hybrid Marguerita $\left(2.39 \mathrm{~kg} \mathrm{~m}^{-2}\right)$ compared with non-hybrid fruits (1.39-1.66 $\mathrm{kg} \mathrm{m}^{-2}$ ). However, in both experiments performed by these authors, as well as in the current cultivation conditions, among the hybrid cultivars, it was possible to observe that some have better adaptability to the organic system than others, and there are also hybrid cultivars with low fruit yield per plant.

The undetermined hybrids Predador and Serato showed better productivity than the determined hybrids Candieiro and Apolo (Figure 1). However, the plants of determined size allowed the production of fruits without the need of axillary shoot cutting and tutoring, minimizing labor costs, a current reality to be considered in the production of tomatoes. Rezende et al. (2004) observed that the cost of labor with tillage/cutting is equivalent to the cost of manual tomato harvesting, representing the two highest costs of tomato fruit production. Another point to be considered should be the reduction of human labor or even avoiding it, due to the shortage of human labor in the field. In this experiment, we observed that the use of determined-type cultivars, e.g., the hybrid Candieiro, may be an alternative for the tomato fruit production, especially under organic conditions, since these cultivars can be cultivated with lower human labor and with shorter cultural cycle, advantageous characteristics for the organic cultivation (Corrêa et al., 2012). The cultivar Candieiro, the third one in fruit productivity $(2.1 \mathrm{~kg} / \mathrm{plant})$, showed a $366 \%$ increase in fruit productivity in the 2 nd cultivation (Table 3 ).

Regarding the ${ }^{\circ}$ Brix content of the fruits, the values ranged from 3.24 (Predator) to 4.45 (Pioneiro). The higher ${ }^{\circ}$ Brix in tomato fruit result in greater sweetness of the fruit and flavor. According to Borguini \& da Silva (2009), the hybrid Carmem showed a higher content of total soluble solids $\left(4.7^{\circ}\right.$ Brix) when cultivated conventionally, while the 
organically cultivated presented a $4.2^{\circ}$ Brix. According to Hauth et al. (2016) the average value of soluble solids found was 4.01 by testing commercial tomato materials for industrial processing in the Sinop-MT region.

An issue still under discussion in organic horticulture refers to the use of $\mathrm{F} 1$ hybrids. In organic tomato production, the use of open-pollinated/creole/Heirloom groups of cultivars was stimulated, mainly because they represent a source of plants with greater genetic variability, leading to better resistance of plants to biotic and abiotic stresses and to cheaper costs of acquisition of seeds compared with F1 hybrids (Toledo et al., 2011).

In the present work, as well as those by other authors, the superiority of the hybrid cultivars in relation to the open-pollinated has been demonstrated. In fact, the openpollinated cultivars can present greater variability due to not having passed by hybridization, which does not always represent gains in relation to fruit yield in the tomato crop, as show in this experiment for organic system. The results obtained in this experiment showed that the use of the Serato F1 hybrid increased fruit yield in $235.5 \%$ when compared with the open-pollinated cultivar Santa Clara. However, Toledo et al. (2011) observed no differences in fruit productivity in the use of "Heirloom" cultivars, openpollinated Santa Clara and Santa Cruz Kada, and some F1 hybrids tested, showing that this response is dependent on specific environment or cultivation conditions.

From the point of view of the greater susceptibility of hybrids to biotic and abiotic factors, this argument is not supported and has no experimental evidence, since in the current experiment, it was generally observed that hybrid cultivars with some specific types of resistance presented higher fruit productivity than non-hybrids. Among the most prominent characteristics of the two most productive cultivars, Serato and Predador, are the resistance to nematodes and TSWV and TYLCV viruses, in which Predador is resistant to both viruses and Serato only to the TSWV . Similarly, Toledo et al. (2011) observed that Santa Clara and Santa Cruz Kada cultivars were also the ones with the lowest fruit yields, 1.39 and $1.66 \mathrm{~kg} \mathrm{~m}^{-2}$, respectively. However, Vargas et al. (2004), using Heirloom tomato cultivars, observed good fruit productivities from 0.7 to $2.7 \mathrm{~kg}$ plant $^{-1}$, showing the use potential of these types of cultivars under organic cultivation.

In relation to abiotic factors, the percentage of plants with symptoms of nutritional deficiency was superior in open-pollinated cultivars than in hybrids (Table 3). Our results, together with results of other authors, showed that under organic systems, the most important is the choice of more adequate cultivars for each environment, regardless if they are Heirloom or F1 Hybrid types, and that the choice of adequate F1 Hybrids can represent an interesting source of available cultivars for some organic productions under greenhouse cultivation. The hybrid cultivars Serato and Predador were the ones with the highest productivity in our experiments in the summer conditions of São Paulo, Brazil, with increases in productivity of 68.6 and $171.8 \%$, respectively, when comparing the two periods of cultivation (Table 3 ).

The use of F1 hybrids depends on acquisition of seeds from specialized companies and represents higher costs than the use of open-pollinated cultivars. In this sense, viewing only the price of the seed does not make sense, but rather one should consider the technology present within the seed, e.g., the resistance to viruses demonstrated in Serato and Predador. The expression of the hybrid vigor present in this type of cultivar as well as the resistance to specific diseases resulted in a great increase of fruit productivity in these cultivars, making possible its cultivation in organic system and generating good fruit productivity, which enable the production of organic tomatoes.

\section{CONCLUSIONS}

The cv. Serato allowed better yields under greenhouse organic cultivation system.

The cv. Candieiro may be beneficial in protected cultivation due to the lower use of labor in the crop and the need to reduce production costs.

The use of hybrid cultivars, which are more productive and resistant to biotic and abiotic factors, makes the organic production of tomatoes economically viable.

Fertilization is a critical factor of the organic production, being necessary experiments to increase fruit productivity, compared to conventional systems.

\section{ACKNOWLEDGEMENTS, FINNANCIAL SUPPORT, AND FULL DISCLOSURE}

AJSR and JCC thank the producer Moisés Santa Rosa, for the infrastructure to carry out the experiment. JCC is grateful to Agristar do Brasil, for the provision of seeds and support to Proex project no. 23112.003078/2016-90 and CNPQ Process 304174/2015-7.

\section{REFERENCES}

Agristar do Brasil (2016) Tomate Serato F1 mostra potencial para cultivo em estufa. Disposable in: http://agristar.com.br/topseedpremium/noticia/detalhe/tomate-serato-f1-mostra-potencialpara-o-cultivo-em-estufa, Accessed in: 13 of August 2018.

Borguini RG \& Silva MV (2009) Características físico-químicas e sensoriais do tomate (Lycopersicon esculentum) produzido por cultivo orgânico em comparação ao convencional. Alimentos e Nutrição, 16:355-361.

Campos De Melo AP, Fernandes PM, Silva-Neto CM \& Seleguini A (2017) Solanáceas em sistema orgânico no Brasil: tomate, batata e physalis. Scientia Agropecuaria, 08:279-290. 
Corrêa AL, Fernandes MCA \& Aguiar LA (2012) Produção de tomate sob manejo orgânico. Rio de Janeiro, Pesagro. 38 p. (Manual Técnico, 36)

Fidélis Junior JB \& Cardoso JC (2016) Seleção de cultivares de tomateiro para sistemas agroecológicos. In: $23^{\circ}$ Congresso de Iniciação Científica da UFSCar, Araras. Anais, SP: UFSCar. p.0123.

Hauth MR, Lamon FR, Botelho SCC \& Fernandes Júnior F (2016) Qualidade de tomates para processamento industrial. In: Jornada Científica da EMBRAPA Agrossilvipastoril. Anais, MT: Embrapa. p.101-104.

He X, Qiao Y, Liu Y, Dendler L, Yin C \& Martin F (2016) Environmental impact assessment of organic and conventional tomato production in urban greenhouses of Beijing city, China. Journal of Cleaning Production, 134:251-258.

Healy GK, Emerson BJ \& Dawson JC (2017) Tomato variety trials for productivity and quality in organic hoop house versus open field management. Renewable Agriculture Food Systems, 32:562-572.

Luz JMQ, Shinzato AV\& Silva MAD (2007) Comparação dos sistemas de produção de tomate convencional e orgânico em cultivo protegido. Bioscience Journal, 23:07-15.

Maciel GM \& Silva EC (2014) Proposta metodológica para quantificação de acilaçúcares em folíolos de tomateiro. Horticultura Brasileira, 32:174-177.

Mansour A, Salem NM, Al-Banna L \& Alsmairat N (2014) Disease management of organic tomato under greenhouse conditions in the Jordan Valley. Crop Protection, 60:48-55.

Melo PCT, Tamiso LG, Ambrosano EJ, Schammass EA, Inomoto MM, Sasaki MEM \& Rossi F (2009) Desempenho de cultivares de tomateiro em sistema orgânico sob cultivo protegido. Horticultura Brasileira, 27:553-559.
O'Connell S, Rivard C, Peet MM, Harlow C \& Louws F (2012) High tunnel and field production of organic heirloom tomatoes: Yield, fruit quality, disease, and microclimate. HortScience, 47:1283-1290.

Pedrosa M, Magalhães KS, Resende FV, França FCT, Silvério TT \& Silva LS (2011) Desempenho de cultivares de tomate em sistema orgânico de produção. Horticultura Brasileira, 29:44454449.

Rezende BLA, Filho ABC \& Martins MIEG (2004) Custo de produção da cultura do tomateiro, em cultivo protegido, em Jaboticabal - SP. Disposable in http://www.abhorticultura.com.br/biblioteca/arquivos/Download/Biblioteca/ cpec2004c.pdf. Accessed in: 13 August 2018.

Schwarz K, Resende JTV, Preczenhak AP, Paula JT, Faria MV \& Dias DM (2013) Agronomic performance and physico-chemical quality in tomato hybrids grown without guiding. Hort. Bras, $31: 410-418$

Toledo DS, Costa CA, Bacci L, Fernandes LA \& Souza MF (2011) Production and quality of tomato fruits under organic management. Horticultura Brasileira, 29:253-257.

Van Bruggen AHC, Gamliel A \& Finckh MR (2016) Plant disease management in organic farming systems. Pest Management Science, 72:30-40.

Van Raij B, Cantarella H, Quaggio JA \& Furlani AMC (1996) Recomendações de adubação e calagem para o Estado de São Paulo. Campinas, IAC. 285p. (Boletim Técnico, 100).

Vargas TO, Souza AC, Alves EP, Barros CS, Oliveira G, Furtado GCW, Abboud ACS \& Araújo ML (2004) Caracterização agronômica de cultivares de tomateiro "Heirloom" sob manejo orgânico no Rio de Janeiro. Disposable in: http://www.abhorticultura.com.br/biblioteca/arquivos/Download/Biblioteca/ 44_103.pdf. Accessed in: 13 August 2018. 